\title{
METODE DA'WAH PONDOK PESANTEN DARUL ULUM DALAM MEMBINA KEAGAMAAN MASYARAKAT DESA SIKAKAP KEPULAUAN MENTAWAI
}

\begin{tabular}{|c|c|c|}
\hline \multicolumn{3}{|c|}{ P-ISSN: 2085-4536 | E-ISSN: 2721-7183 } \\
\hline Link: https://jurnal-stidnatsir.ac.id/index.php/dakwah/article/view/42 \\
\hline \multicolumn{2}{|c|}{ DOI : https://doi.org/10.38214/jurnaldawahstidnatsir.v2i01.42 } \\
\hline Dikirim: 25-03-2019 & Direview: 05-04-2019 & Diterbitkan: 17-04-2019 \\
\hline $\begin{array}{c}\text { UJANG HABIBI } \\
\text { STID Mohammad Natsir - Indonesia } \\
\text { habibi@stidnatsir.ac.id }\end{array}$ & $\begin{array}{c}\text { PUJI UTAMI } \\
\text { Ponpes Darul Ulum - Indonesia } \\
\text { pujiutami@gmail.com }\end{array}$ \\
\hline \begin{tabular}{c} 
pulatial \\
\hline
\end{tabular}
\end{tabular}

\begin{abstract}
ABSTRAK
Tujuan Penelitian: Fokus masalah yang dikaji adalah bagaimana Metode Da'wah Pondok Pesanten Darul Ulum Dalam Membina Keagamaan Masyarakat Desa Sikakap Kepulauan Mentawai. Metode Penelitian: Untuk mengetahui tujuan penelitian ini maka peneliti menggunakan metode kualitatif dengan melakukan tiga langkah yaitu: penggalian data kepada objek penelitian, observasi lapangan, dan wawancara kepada narasumber primer (pengurus pondok pesantren). Hasil Penelitian: Dari data dan observasi, dapat diperoleh kesimpulan bahwa pondok pesantren Darul Ulum menerapkan empat metode da'wah dalam membina keagamaan masyarakat desa Sikakap yaitu: pertama, dengan pendekatan personal melalui komunikasi lisan (verbal communication) dalam bentuk pengajian atau ceramah rutin dan dengan sentuhan hati dalam bentuk pembagian daging qurban. kedua, dengan pendekatan pendidikan dalam bentuk training imam dan khatib, pelatihan guru al-qur'an, dan pembinaan muallaf. ketiga, dengan pendekatan penawaran dalam bentuk memberikan janji bagi santri yang berprestasi akan diberikan beasiswa belajar ke luar kota. keempat, dengan pendekatan misi/bi'tsah, dalam bentuk mengirimkan imam shalat taraweh ramadhan ke berbagai masjid dan mushalla se kepulauan Mentawai.
\end{abstract}

Kata Kunci: Metode, Da'wah, Keagamaan, Sikakap

\section{PENDAHULUAN}


Da'wah merupakan aktifitas untuk mengajak manusia agar berbuat kebaikan dan menurut petunjuk Al-Qur'an dan Sunnah Nabi Muhammad SAW., menyeru untuk berbuat kebajikan dan melarang kepada perbuatan munkar agar mendapatkan kebahagiaan di dunia dan akhirat. ${ }^{1}$ Disamping itu da'wah juga dapat dimaknai sebagai usaha dan aktifitas orang beriman dalam mewujudkan ajaran islam dengan menggunakan sistem dan cara tertentu. Da'wah berfungsi untuk menyampaikan nilai-nilai dan ajaran Islam untuk membentuk masyarakat yang berkualitas, memiliki peradaban yang baik dan menjadi umat terbaik.

Merupakan suatu kenikmatan besar yang AllahSWT berikan bagi siapa yang melakukan da'wah.Karena da'wah merupakan warisan para Nabi dan Rasul.Sehingga para da'i merupakan penerus tugas para Nabi dan Rasul. Hal ini merupakan bukti keislaman dan akan mendapatkan kedudukan mulia serta mendapat kemenangan di akhirat nanti.

'Dan hendaklah ada di antara kamu segolongan umat yang menyeru kepada kebajikan, menyuruh kepada yang ma'ruf dan mencegah dari yang munkar, merekalah orang-orang yang beruntung”. (QS. Ali Imran: 104)

"Siapakah yang lebih baik perkataannya daripada orang yang menyeru kepada Allah, mengerjakan amal yang saleh, dan berkata: "Sesunggubnya aku Termasuk orangorang yang

menyerah diri?”. (QS. Fushshilat : 33)

Keberhasilan da'wah Rasulullah `teruji dengan banyaknya tantangan dan hambatan yang beliau hadapi. Namun, hasil usaha yang beliau lakukan dapat disaksikan dengan tumbuh dan berkembangnya Islamdiberbagai belahan dunia menyusuri wilayah Asia, Afrika, Amerika dan Eropa.Banyak faktor yang menjadi sebab berhasilnya da'wah Rasulullah `, diantaranya adalah metode da'wah yang beliau gunakan. Oleh karena itu, metode da'wah Rasulullah ` lah yang harus menjadi satu-satunya acuan bagi para da'i. Karena Rasulullah 'merupakan hamba pilihan Allah f yang memiliki teladan dan patut dicontoh oleh umatnya. Rasulullah 'telah berhasil mengembangkan Islam keseluruh penjuru dunia atas petunjuk Allah $\mathrm{f}$.

\footnotetext{
${ }^{1}$ Samsul Munir Amir, Ilmu Da'wah, Amzah : Jakarta, 2009, hal. xviiiswm
} 
"Sesunggubnya telah ada pada (diri) Rasulullah itu suri teladan yang baik bagimu (yaitu) bagi orang yang mengharap (rahmat) Allah dan (kedatangan) hari kiamat dan Dia banyak menyebut Allab”. (QS. Al-Ahzab : 21)

"Serulah (manusia) kepada jalan Tuhan-mu dengan bikmahdan pelajaran yang baik dan bantablah mereka dengan cara yang baik. Sesunggubnya Tuhanmu Dialah yang lebih mengetabui tentang siapa yang tersesat dari jalan-Nya dan Dialah yang lebih mengetabui orang-orang yang mendapat petunjuk”.'(QS. An-Nahl :125)

"Maka disebabkan rabmat dari Allah-lah kamu Berlaku lemah lembut terhadap mereka.Sekiranya kamu bersikap keras lagi berhati kasar, tentulah mereka menjaubkan diri dari sekelilingmu.karena itu ma'afkanlab mereka, mohonkanlab ampun bagi mereka, dan bermusyawaratlab dengan mereka dalam urusan itu[2467. kemudian apabila kamu telah membulatkan tekad, Maka bertawakkallah kepada Allah. Sesunggubnya Allab menyukai orang-orang yang bertawakeal kepada-Nya". (QS. Ali Imran : 159)

Pada zaman modern ini, perkembangan dan kemajuan teknologi yang begitu cepat, sangat berpengaruh bagi kehidupan manusia.Hal ini tidak bisa dihindari karena, perkembangan dan kemajuan teknologi akan berjalan sesuai dengan kemajuan ilmu pengetahuan.Perkembangan dan kemajuan teknologi memiliki dampak positif bagi kehidupan manusia.Hal ini dapat disaksikan dengan munculnya alat-alat teknologi pada saat ini yang memberikan kemudahan dan manfaat dalam berbagai bidang dan pekerjaan. Misalnya, dalam bidang informasi untuk mendapatkan atau menyampaikan informasi, masyarakat memanfaatkan radio atau surat kabar. Saat ini, dengan adanya kemajuan teknologi, masyarakat dapat menggunakan televisi, handphone, jaringan internet dan sebagainya untuk mendapatkan dan menyampaikan informasi yang dapat di akses secara lebih cepat.

Namun tidak dapat dipungkiri, selain memberikan banyak manfaat dan dampak yang positif bagi kehidupan manusia, perkembangan dan kemajuan teknologi pula dapat mendatangkan dampak negatif bagi kehidupan.Seharusnya, dengan diciptakannya telivisi, handphone, jaringan internet dan sebagainya, hal ini dapat menjadi sarana untuk mempermudah manusia mendapatkan ilmu dan pendidikan serta informasi.Namun yang muncul adalah siaran-siaran televisi, film-film dan sebagainya yang kurang mendidik, serta kemudahan dan bebasnya mengakses internet yang dapat 
dilakukan oleh siapapun dan dimanapun, yang pada akhirnya dapat membuka peluang untuk melakukan prilaku yang menyimpang.Seperti maraknya perjudian, zina, kasus narkoba, dan tindakan kriminal lainnya.

Ledakan kemajuan teknologi dalam berbagai bidang yang memberikan dampak positif maupun negatif bagi kehidupan masyarakat, tidak boleh dibiarkan lewat begitu saja.Seruan kebajikan dan mencegah segala bentuk kemunkaran harus tetap digulirkan.Hal ini dilakukan untuk mengontrol dan mengawasi kehidupan masyarakat, agar tidak melakukan penyimpangan dalam bentuk apapun akibat kemajuan dan perkembangan teknologi saat ini.Karena melalui tayangan-tayangan televisi yang kurang mendidik serta kemudahan akses internet inilah bisa membentuk kepribadian seseorang yang cenderung melakukan penyimpangan.

Jika kita kembali menoleh kebelakang, mengangkat wacana da'wah Islam di Indonesia yang dilakukan oleh tokoh-tokoh Islam terdahulu, mereka telah mencurahkan sisa hidup mereka untuk melakukan upaya da'wah.Dengan keterbatasan sarana dan prasaranapada waktu itu.Para wali songo berda'wah dengan menyebarkan ilmu dan agama ditanah Jawa, KH.Hasyim Asy'ari dengan Nahdlatul Ulama dan lembaga pendidikannya, serta KH.Ahmad Dahlan dengan Muhammadiyyah dan lembaganya pendidikannya. ${ }^{2}$ Karena dengan da'wah Islamdapat mengantisipasi dan memperkuat benteng aqidah masyarakat dan generasi muda masa mendatang. Adapun tujuan khusus konsep pendidikan Islam dalam proses pendidikan adalah untuk meningkatkan keimanan, pemahaman, penghayatan, dan pengalaman tentang ajaran Islam. Sehingga menjadi manusia yang beriman dan bertaqwa serta berakhlaq mulia dalam kehidupan bermasyarakat, berbangsa dan bernegara. ${ }^{3}$

Sarana yang dipakai oleh para founding father dan tokoh-tokoh terdahulu dalam menda'wahkan Islam pada waktu itu adalah adalah mendirikan wadah pembinaan dan pendidikan yang berbentuk madrasah, pondok pesantren atau sekolah-sekolah berbasis Islam. Tentunya, pendirian madrasah, pondok pesantren dan sekolah-sekolah tersebut dijadikan sebagai tempat pembinaan bagi masyarakat dan kaderisasi untuk

\footnotetext{
${ }^{2}$ Nur Zazin, Gerakan Menata Pendidikan (Teori dan Aplikasi), Jogjakarta : Arruzz Media. 2011, hal.21

${ }^{3}$ M. Athiyah Al-Abrasyi, Dasar-dasar Pokok Pendidikan Islam,Jakarta : PT. Bulan Bintang, 1995, hal. 19
} 
melahirkan generasi masa depan yang beriman dan bertaqwa serta berakhlaq mulia. Dan sampai saat ini masih dapat ditemui wadah pendidikan peninggalan mereka, seperti Pondok Pesantren Tebu Ireng yang terletak di Jombang, Jawa Timur, Mu'alimin Muhammadiyyah, Muallimat Muhammadiyyah dan sebagainya.Yang kemudian semakin berkembang dan meluas diseluruh penjuru Indonesia.Itu semua merupakan hasil buah fikiran mereka yang menjadi cikal bakal berdirinya lembaga-lembaga pendidikan Islam dan pesantren-pesantren sebagai wadah pembinaan bagi masyarakat dan kaderisasi generasi saat ini dan masa mendatang.

Pondok pesantren merupakan salah satu wadah pendidikan klasik di Indonesia yang di dalamnya terdapat kiyai (pendidik) yang mengajar dan mendidik para santri (peserta didik) dengan sarana masjid sebagai tempat untuk menyelenggarakan pendidikan tersebut, dengan materi pengajaran kitab-kitab klasik para ulama dan kitab-kitab umum. Tujuannya adalah untuk menguasai ilmu agama islam secara detail, serta mmengamalkannya sebagai pedoman hidup dengan menekankan pentingnya moral, adab dan akhlaq dalam kehidupan bermasyarakat. Didalamnya pula didukung dengan adanya pemondokan atau asrama sebagai tempat tinggal para santri. ${ }^{4}$

Pondok pesantren, dari waktu ke waktu terus mengalami penyesuaian dalam hal konsep perkembangan ilmu pengetahuan dan teknologi.Sehingga, tidaklah benar jika terdapat sebagian masyarakat umum yang mengidentikkan pondok pesantren sebagai tempat pendidikan anti perubahan, konservatif (tradisional), ataupun tidak demokratis dan sebagainya. Padahal, dengan adanya pondok pesantren inilah pembinaan masyarakat, kaderisasi dan antisipasi pengaruh buruk modernisasi generasi masa depan dilakukan.

Melihat gerak langkah da'wah yang dilakukan oleh para pendahulu, Ustadz Iswandi bersama para tokoh-tokoh muslim yang lain, pada tahun 2012 mendirikan Pondok Pesantren Darul Ulum di desa Sikakap. Desa Sikakap merupakan desa yang berada di kawasan Kepulauan Mentawai, provinsi Sumatra Barat.Di desa tersebut, Separuh dari penduduknya adalah

${ }^{4}$ Abdul Mujib, Ilmu Pendidikan Islam,Jakarta :Kencana Penada Media, 2006, hal. 234-235 
perantauan dari Padang, Jawa, Nias, Medan, dan selebihnya adalah masyarakat pribumi.

Dari sejak didirikannya hingga saat ini, Pondok Pesantren Darul Ulum telah mendapatkan pengakuan dan tetap dipercayai oleh masyarakat Sikakap.Khususnyasebagai tempat pembinaan keagamaan masyarakat dan pengkaderan melauli pendidikan Islam yang baik.Hal itu dibuktikan dengan dukungan dan sokongan dari masyarakat sampai saat ini.Dengan kondisi pada waktu itu minimnya lembaga-lembaga pendidikan disekitar pondok pesantren. Hal ini terjadi karenametode da'wah dan pembinaan agama Islam yang baik, yang dilakukan oleh pimpinan beserta seluruh pengurus Pondok Pesantren Darul Ulum kepada masyarakat, sehingga masyarakat faham pentingnya pendidikan dan pemahaman agama Islam bagi generasi mendatang.

Dengan keadaan masyarakat sikakap dan sekitarnya yang didominasi umat beragama Nasrani, tidak menyurutkan eksistensi Pesantren Darul Ulum dalam melakukan pembinaan keislama pada masyarakat Muslim Desa Sikakap, Kecamatan Sikakap.Pembinaan keagamaan ini terus dilakukan oleh Pondok Pesantren Darul Ulum agar masyarakat tidak salah dalam memahami Islam dan tetap terjaga dalam koridor Islam.Sehingga masyarakat dapat menghadapi kuatnya arus modernisasi dan dampak buruk dari perkembangan dan kemajuan teknologi yang cenderung mengarahkan kepada perbuatan menyimpang.

Pembinaan-pembinaan keagamaan Islam kepada masyarakat desa Sikakap khususnya, yang dilakukan Pondok Pesantren Darul Ulum diantaranya adalah untuk menjaga serta mengarahkan masyarakat kepada hal yang lebih baik dalam aspek aqidah, syari'ah dan ibadah, serta akhlaq. Diantara bentuk pembinaan yang dilakukan adalah pendidikan formal di pondok pesantren, mengadakan pengajian-pengajian rutin untuk para Muallaf, pelatihan imam dan khatib, mengutus da'i (santri) ke desa-desa sekitaran Sikakap.

Berdasarkan latar belakang diatas, maka penulis tertarik untuk meniliti lebih dalam dan akan dituangkan dalam tulisan skripsi ini, tentang bentuk-bentuk pembinaan keagaman yang dilakukan oleh Pondok Pesantren Darul Ulum kepada masyarakat desa Sikakap, serta menganalisis bagaimana metode da'wah yang digunakan berdasarkan pembinaanpembinaan keagamaan yang dilakukan. Oleh karena itu, penulis mengambil 
judul penelitian "Metode Da'wah Pondok Pesantren Darul Ulum Dalam Pembinaan Keagamaan Terhadap Masyarakat Desa Sikakap".

\section{HASIL DAN DISKUSI}

\section{Profil Pondok Pesantren Darul Ulum dan Desa Sikakap}

\section{Profil Pondok Pesantren Darul Ulum}

Gagasan awal berdirinya Pondok Pesantren Darul Ulum lahir dari seorang da’i dan juga perantauan yang bernama Iswandi pada tahun 2012. Iswandi mengemukakan gagasan itu kepada teman-teman seperjuangannya di desa Sikakap. Gagasan itu bergulir seiring terjadinya beberapa masalah yang sangat mendasar di Desa Sikakap, diantaranya adalah tersebarnya kaum muslimin di kampung-kampung yang jaraknya sangat jauh dari pusat kecamatan, sehingga mengakibatkan anak-anak muslim yang ingin melanjutkan sekolah harus mencari tempat tinggal sendiri di Kecamatan, karena sekolah hanya tersedia di kecamatan. Keadaan ekonomi orang tua yang sangat dibawah rata-rata mengakibatkan anak-anak ini tidak sanggup untuk tinggal di rumah kontrakan atau rumah kos, ahirnya mereka tinggal di rumah-rumah kosong tidak layak huni dan sebagian bekerja di rumah sebagian masyarakat tanpa ada bayaran. Masyarakat Sikakap pada umum nya mengenal anak-anak muslim ini dengan anak-anak yang kotor, kumuh, bau, bahkan tuduhan-tuduhan pencurian kerap kali mereka rasakan. Keadaan yang sangat memilukan inilah yang mendorong Iswandi dan rekan-rekannya untuk mengumpulkan mereka dalam sebuah Pondok Pesantren.

Iswandi dan rekan-rekannya memberi nama Darul Ulum untuk pesantren yang ia dirikan. Kata Darul Ullum berasal dari bahasa arab yang berarti rumah ilmu atau pusat ilmu, denganharapanpesantreninikelakmejadipusatilmupengetahuan di seluruhSikakapkhususnya dan Mentawai umumnya.

Untuk memulai aktivitasnya, Iswandi bersama rekan-rekannya harus membentuk sebuah yayasan resmi untuk wadah bagi pesantrennya. Setelah itu Iswandi mengunjungi kampung-kampung muslim di pedalaman Sikakap untuk meminta izin kepada orang tua yang anaknya ada di Sikakap agar bersedia menempatkan anaknya tinggal di Pesantren. 
Pada awal berdirinya tahun 2013, Pondok Pesantren Darul Ulum menyewa sebuah gedung berukuran $6 \times 7 \mathrm{~m}$ di pinggiran desa Sikakap. Gedung inilah yang menjadi asrama sekaligus ruang belajar untuk para santri dan santriwati yang berjumlah 22 anak dan seorang Pembina. Semua santri ini masih berada pada tingkat pendidikan Ibtidaiyah atau setara dengan sekolah dasar. Mereka sekolah di Madrasah Ibtidaiyah Swasta (MIS) Sikakap.

Pada akhir tahun 2013, Pesantren Darul Ulum mendapatkan perhatian dari Dewan Da'wah Islamiyah Indonesia melalui seorang da'i nya yang bertugas di kampung muslim Tubeket. Melihat keadaan Pesantren yang memprihatinkan itu, Dewan Da'wah berusaha mencarikan donator untuk Pesantren Darul Ulum, sehingga pada tahun 2014 ada seorang donatur yang bersedia untuk mewaqafkan hartanya untuk perkembangan Pesantren. Kemudian dibelilah tanah seluas $450 \mathrm{~m}^{2}$, tanah yang masih semak belukar ini dibersihkan secara bergotong royong oleh warga dan seluruh wali santri yang dari pedalaman Sikakap. Setelah bersih dari semak belukar, gotong royong dilanjutkan dengan mendaftarkan tanah yang masih miring. Para santripun semangat ikut gotong royong setelah pulang sekolah.

Kemudian dibangunlah sebuah gedung berukuran 7 x $18 \mathrm{~m}$. Di akhir tahun 2014 bangunan ini sudah selesai, sehingga semua santri bersama pembinanya berbondong-bondong mengangkut barang-barang pribadi dan pesantren untuk dipindahkan ke asrama baru. Bukan hanya sampai disini saja, Dewan Da'wah mencarikan donator lagi untuk operasional dan konsumsi harian Pesantren, bahkan sampai sekarang. Kemudian mengirimkan da'i nya untuk mebantu pembinaan santri.

Berdirinya Pondok Pesantren Darul Ulum berpengaruh besar terhadap perkembangan keagamaan masyarakat desa Sikakap dan sekitarnya. Hal ini ditunjukkan dengan terjadinya hubungan erat antara Pondok Pesantren dengan masyarakat, Pemerintah daerah, Departemen Sosial, Departemen Agama.

Secara kelembagaan, Pondok Pesantren Darul Ulum berada di bawah yayasan Darul Ulum. Untuk menunjang kelangsungan pesantren, Iswandi Juga mendaftarkan yayasan Darul Ulum sebagai panti Asuhan yang dikelola bersama dengan Dinas Sosial Kabupaten dan Propinsi. Dengan 
adanya Panti Asuhan ini Pondok Pesantren mendapatkan bantuan subsidi, biaya bulanan, bantuan uang saku, buku dan sebagainya.

Semenjak adanya Da'i, Pondok Pesantren Darul Ulum lebih focus mencirikan dirinya sebagai Pondok Pesantren Tahfidzul-Qur'an yang mendidik santrinya agar mempunyai keunggulan dalam aspek Al-Qur'an.

Para santri yang tinggal di Pesantren Darul Ulum masih sekolah formal di luar pesantren, mulai dari tingkat Madrasah Ibtidaiyah maupun Tsanawiyah. Pada tahun 2017, Pesantren Darul Ulum mendirikan Madrasah Aliyah (MA) atau setara dengan Sekolah Menengah Atas (SMA) dikarenakan tuntutan yang sangat mendesak, yaitu sebagian santri Pesantren Darul Ulum sudah menyelesaikan pendidikan Menegah Pertama (SMP), sehingga mereka membutuhkan sekolah dengan nuansa islami tingkat Atas. Madrasah Aliyah didirikan untuk menyelamatkan santri agar tidak sekolah di sekolah umum, dikarenakan sekolah-sekolah umum yang ada di Sikakap mulai dari tingkat dasar sampai tingkat atas didominasi oleh siswa-siswi dari Agama Nasrani, yang otomatis pergaulan dan cara hidup sesuai dengan Agama yang mereka anut.

Untuk kelangsungan proses pembinaan dan kehidupan sehari-hari di Pondok Pesantren, maka disediakan sarana dan prasarana seadanya seperti, 2 ruang lokal belajar, 2 Ruang asrama, Mushalla (tempat ibadah), 3 ruang Pembina, 1 rumah da'i, 1 lapangan olah raga, 1 kantin, 1 ruang mudir dan kepala Sekolah, 6 ruang WC dan kamar mandi santri dan 3 kamar mandi Pembina.

Sarana dan prasarana tersebut semuanya dibangun dengan menggunakan dana yang berasal dari para donatur.

Pada bidang non fisik, Pondok Pesantren Darul Ulum akan mengembangkan kerjasama yang saling menguntungkan dengan para donatur, para orang tua santri, masyarakat, lembaga-lembaga swasta, tokoh agama dan masyarakat umum ${ }^{5}$

Adapun struktur kepengurusan pondok pesantren Darul Ulum penulis sajikan melalui gambar struktur kepungurusan sebagai berikut :

${ }^{5}$ Iswandi, MudirPondokPesantrenDarulUlum, Wawancara, Sikakap, Rabu 18 September 2019 


\section{Gambar 1}

Struktur pengurus pondok pesantren

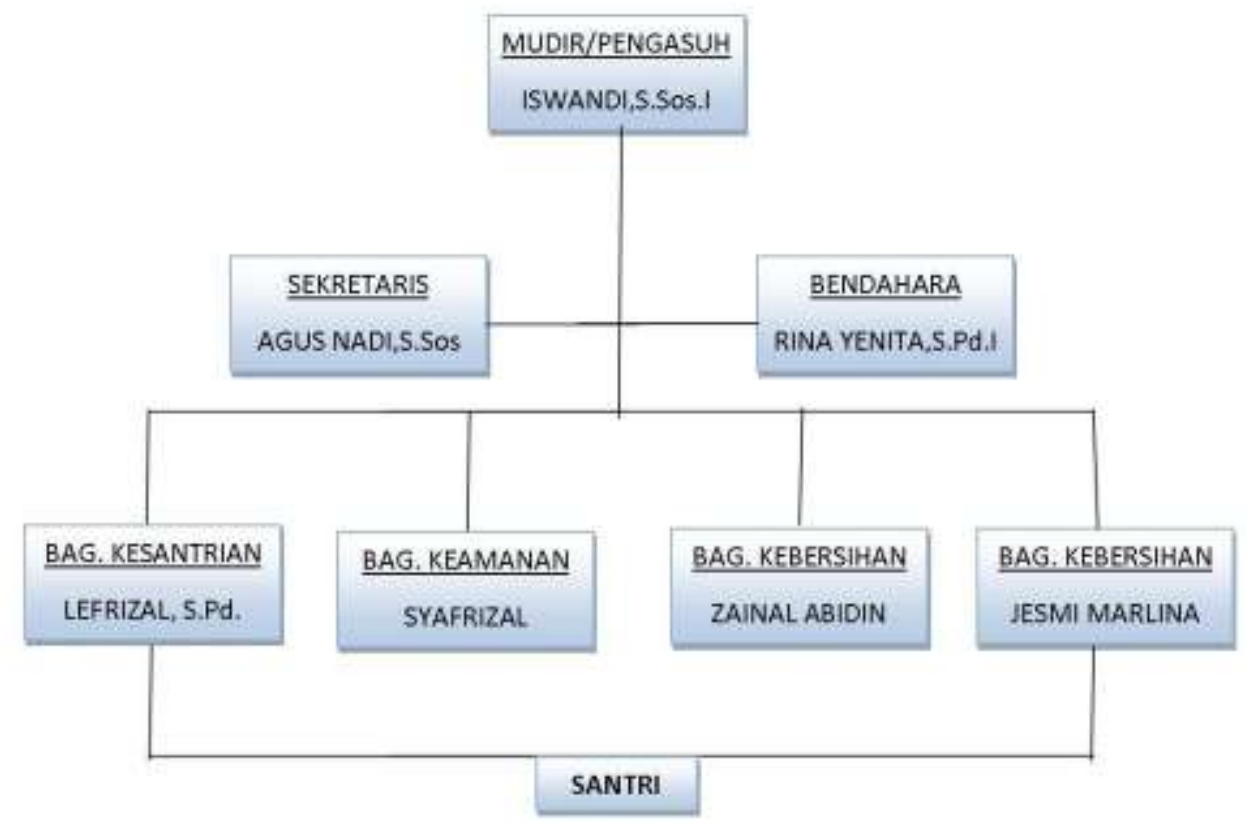

\section{Profil Desa Sikakap}

Desa Sikakap merupakan salah satu desa dari tiga desa di wilayah Kecamatan Sikakap, Kabupaten Kepulauan Mentawai.

\section{a. Kondisi Geografis Desa Sikakap}

Desa Sikakap memiliki batas-batas wilayah sebagai berikut:

Sebelah Utara

Sebelah Timur

Sebelah Barat

Sebelah Selatan
: Desa Matobe

: Selat Mentawai

: Taikako

: Desa Makalo 


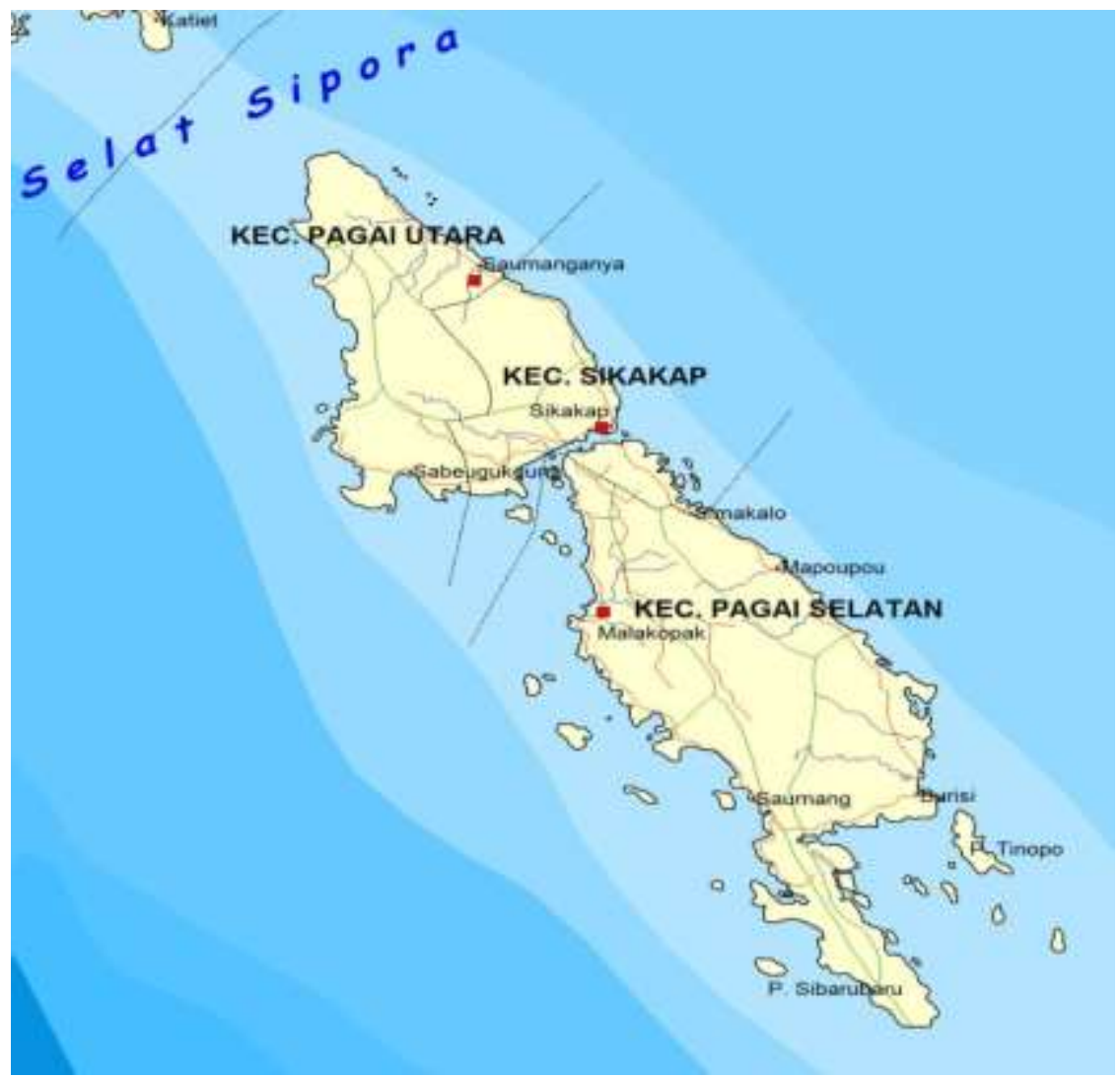

b. Penggunaan/keadaan Lahan

Luas desa Sikakap adalah 22.493 ha dengan penggunaan lahan adalah sebagai berikut :

\begin{tabular}{|c|c|c|}
\hline No & Penggunaan Lahan & LuasTanah \\
\hline 1. & Topografi/Bentang Lahan & \\
\hline a. & Dataran & $: \quad 7.000$ \\
\hline b. & Perbukitan/Pegunungan & $: 10.000 \mathrm{Ha}$ \\
\hline
\end{tabular}




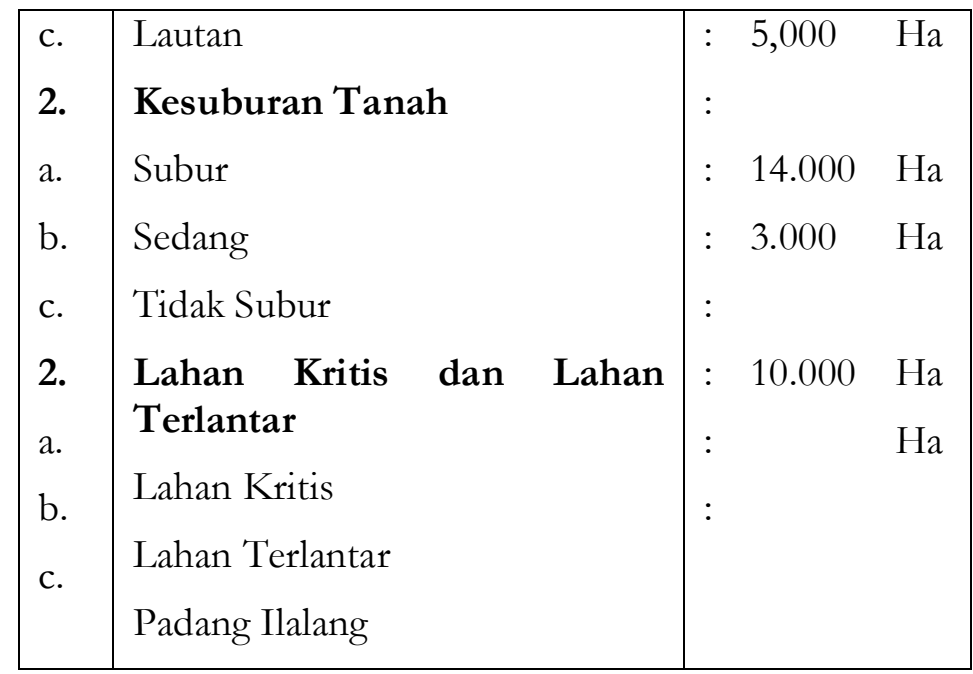

\section{c. Wilayah Administratif Pemerintah Desa}

Jarak pusat pemerintahan desa dengan pusat pemerintahan Kecamatan Sikakap sejauh $500 \mathrm{~m}$ dengan waktu tempuh 5 menit. Sedangkan ke pusat pemerintah Kabupaten sejauh $100 \mathrm{Km}$ dengan waktu tempuh $10 \mathrm{Jam}$.

\section{d. Gambaran Umum Demografis}

Jumlah penduduk sampai dengan tahun 2016 adalah sebanyak 1.334 Kepala Keluarga, dengan jumlah jiwa sebanyak 5.551 orang yang terdiri dari 2.771 orang laki-laki dan 2.780 orang perempuan.

\section{(1) Klasifikasi Penduduk Menurut Kelompok Umur}

\begin{tabular}{|l|l|l|}
\hline NO & UMUR & JUMLAH \\
\hline 1 & Di bawah 0-6 Tahun & 504 orang \\
\hline
\end{tabular}




\begin{tabular}{|l|l|l|}
\hline 2 & $6-17$ Tahun & 1405 orang \\
\hline 3 & $17-50$ Tahun & 3094 orang \\
\hline 6 & 50 tahun ke atas & 471 orang \\
\hline
\end{tabular}

(2) Klasifikasi Penduduk Menurut Pendidikan

\begin{tabular}{|l|l|l|}
\hline No & Tingkat Pendidikan & Jumlah \\
\hline \multicolumn{2}{|l|}{ Lulusan Pendidikan Umum } & \\
\hline 1 & TK/belum Sekolah & 715 orang \\
\hline 2 & SD & 1.481 orang \\
\hline 3 & SLTP & 1.444 orang \\
\hline 4 & SLTA & 1.564 orang \\
\hline 5 & S1 & 373 orang \\
\hline & & \\
\hline
\end{tabular}

(3) Klasifikasi Penduduk Menurut Agama

\begin{tabular}{|l|l|c|}
\hline No & Agama & Jumlah \\
\hline 1 & Islam & 2.675 \\
\hline 2 & Protestan & 2.404 \\
\hline 3 & Katolik & 472 \\
\hline
\end{tabular}

\section{e. Kondisi Ekonomi}

Penduduk Desa Sikakap yang berjumlah 5.551 jiwa dengan mata pencaharian adalah di bidang swasta, pertanian, nelayan dan lain-lain, dengan rincian sebagai berikut:

\begin{tabular}{|l|l|l|}
\hline NO & PROFESI/PEKERJAAN & JUMLAH \\
\hline
\end{tabular}




\begin{tabular}{|l|l|l|}
\hline 1 & Rumah tangga & 1153 orang \\
\hline 2 & Nelayan & 211 orang \\
\hline 3 & Wiraswasta & 593 orang \\
\hline 4 & Pegawai Honor & 121 orang \\
\hline 5 & TNI dan Polisi & 24 orang \\
\hline 6 & Pensiunan & 26 orang \\
\hline 7 & Petani & 398 orang \\
\hline 8 & Mahasiswa & 742 orang \\
\hline 9 & Pelajar & 1290 orang \\
\hline 10 & Pegawai Agama & 36 orang \\
\hline 11 & Pedagang & 125 orang \\
\hline 12 & Karyawan BUMN & 7 orang \\
\hline
\end{tabular}

\section{f. Keadaan Sosial Sarana dan Prasarana Desa}

\section{1) Sarana Pendidikan Agama}

Penduduk Desa Sikakap menganut agama Kristen, Islam, Katolik dengan sarana prasarana peribadatan dan pendidikan terdiri atas:

\begin{tabular}{|l|l|l|}
\hline No & Keterangan & Jumlah \\
\hline a. & Jumlah Masjid & 6 buah \\
b. & Jumlah mushalla & 5 buah \\
c. & Jumlah Gereja & 11 buah \\
e. & Pondok Al Qur'an/ TPQ & 1 buah \\
f. & MDA/TPA & 7 buah \\
\hline
\end{tabular}

2) Sarana Olah Raga 
Sarana olah raga yang ada di Desa Sikakap adalah:

\begin{tabular}{|l|l|l|}
\hline No & Sarana Olah Raga & Jumlah \\
\hline a. & Lapang Sepak bola & 2 buah \\
b. & Lapang volyball & 4 buah \\
c. & Lapang Bulutangkis & 1 buah \\
\hline
\end{tabular}

\section{g. Potensi Unggulan Desa}

Desa Sikakap merupakan salah satu desa di Kecamatan Sikakap, yang daerahnya berupa perbukitan dan dataran, dengan sumber potensi yang dimiliki yaitu:

(1) Produksi dari hasil hutan rakyat berupa kayu dan rotan

(2) Produksi dari hasil kebun masyarakat berupa pisang, keladi, pinang dan cengkeh

(3) Produksi dari hasil home industri; kripik pisang, kripik keladi.

(4) Ternak kambing dan sapi karena lahan yang subur menyediakan rerumputan yang besar.

(5) Budidaya ikan air tawar berupa pembesaran ikan Nila, Lele dan sidat

(6) Produk kerajinan/handcraft yaitu kerajinan bambu.

\section{h. Sosial Budaya}

Di desa Sikakap, masyarakat nya terdiri dari berbagai suku seperti suku Mentawai, Minang, Batak, Nias, Jawa dan lain lain. Pada umumnya penduduk Sikakap berbaur satu sama lain namun tetap harmonis. Sesuai dengan komposisi masyarakatnya yang heterogen masing-masing kelompok masyarakat mempunyai budaya dan adat istiadat sendiri. 


\section{i. Lingkungan Hidup dan Kesehatan Masyarakat}

Kondisi lingkungan masyarakat jika ditinjau dari sisi kebersihan, dan sanitasi di Desa Sikakap masih kurang. Masih perlunya digalakan budaya Perilaku Hidup Bersih dan Sehat. Belum adanya program pengelolaan sampah dan limbah rumah tangga yang baik, masih banyak masyarakat Desa Sikakap belum memiliki jamban sendiri. Beberapa masyarakat hanya mengandalkan kolam miliknya untuk di jadikan MCK.

Air minum masyarakat menggunakan mata air perbukitan yang disalurkan melalui selang/pipa pralon. Secara kelembagaan sudah ada posyandu dan posyandu lansia, namun masih belum optimal. Masih banyak lansia yang memerlukan pendampingan. Selain itu masih ditemukannya kasus balita gizi buruk.

Sarana kesehatan desa Sikakap terdiri atas;

\begin{tabular}{|l|l|l|}
\hline No & Sarana Kesehatan & Jumlah \\
\hline a. & Puskesmas & 1 unit \\
b. & Balai Pelayanan Masyarakat & 3 unit \\
c. & Posyandu & 6 unit \\
d. & Apotik/ Depot Obat & 5 unit \\
\hline
\end{tabular}

\section{j. Lembaga Pendidikan dan Kondisi Pendidikan}

Desa Sikakap memiliki sarana pendidikan baik pendidikan formal maupun pendidikan non formal yaitu:

\begin{tabular}{|l|l|l|}
\hline No & Sarana Pendidikan & Jumlah \\
\hline I. & Pendidikan Formal & \\
\hline
\end{tabular}




\begin{tabular}{|c|c|c|}
\hline $\begin{array}{l}\text { a. } \\
\text { b. } \\
\text { c. } \\
\text { d. } \\
\text { e. } \\
\text { II. } \\
\text { a. } \\
\text { b. }\end{array}$ & $\begin{array}{l}\text { Pendidikan Anak Usia Dini } \\
\text { (PAUD) } \\
\text { Taman Kanak-Kanak (TK) } \\
\text { SD/ MIN } \\
\text { SLTP/ MTsN } \\
\text { MAS } \\
\text { Pendidikan Non Formal } \\
\text { TPQ } \\
\text { Madrasah Diniyah } \quad \text { (MD) }\end{array}$ & $\begin{array}{l}12 \text { unit } \\
1 \text { unit } \\
8 \text { unit } \\
2 \text { unit } \\
1 \text { Unit }\end{array}$ \\
\hline
\end{tabular}

Sarana/fasilitas pendidikan formal sudah mencukupi. Sedangkan untuk sarana pendidikan non formal seperti TPQ dan MD masih terbatas dan belum layak. ${ }^{6}$

\section{A. Analisis Metode Da'wah Pondok Pesantren Darul Ulum Dalam Pembinaan Keagamaan Terhadap Masyarakat Desa Sikakap}

Pondok Pesantren Darul Ulum merupakan suatu institusi pendidikan yang konsisten dalam pelaksanaan da'wah dan penyebaran nilai-nilai keIslaman di lingkungannya yaitu masyarakat desa Sikakap. Dalam pengelompokan mad'u berdasarkan tipologi dan klasifikasi masyarakat, masyarakat desa Sikakap tergolong tipe masyarakat pengikut akhir. Tipe masyarakat pengikut akhir yaitu, masyarakat yang ekstra hatihati, sehingga berdampak kepada anggota masyarakat untuk bersikap skeptis terhadap pembaharuan. Karena factor kehati-hatian yang berlebihan ini, maka setiap gerakan pembaharuan memerlukan waktu dan pendekatan yang sesuai untuk bias masuk dan melakukan pembaharuan.

${ }^{6}$ Arsip Desa Sikakap, Profil Desa Sikakap, Kecamatan Sikakap, Kabupaten Kepulauan Mentawai, Provinsi Sumatera Barat 2019 
Pengelompokan mad'u berdasarkan tipologi dan klasifikasi masyarakat ini disebutkan oleh M. Bahri Ghazali dalam bukunya Da'wah Komunikatif, diantaranya yaitu:

1. Tipe innovator, yaitu masyarakat yang memiliki keinginan keras pada setiap fenomena sosial yang sifatnya membangun, bersifat agresif dan tergolong memiliki kemampuan antisipatif dalam setiap langkah.

2. Tipe pelopor, yaitu masyarakat yang selektif dalam menerima pembaharuan dalam membawa perubahan positif. Untuk menerima atau menolak ide pembaharuan, mereka mencari pelopor yang mewakili mereka dalam menggapai pembaharuan itu.

3. Tipe pengikut dini, yaitu masyarakat sederhana yang kadangkadang kurang siap mengambil resiko dan umunya lemah mental. Kelompok masyarakat ini adalah kelompok kelas dua di masyarakatnya, mereka perlu seorang pelopor dalam mengambil tugas kemasyarakatan.

4. Tipe pengiku takhir, yaitu masyarakat yang ekstra hati-hati sehingga berdampak kepada anggota masyarakat untuk bersikap skeptic terhadap pembaharuan. Karena factor kehati-hatian yang berlebihan ini, maka setiap gerakan pembaharuan memerlukan waktu dan pendekatan yang sesuai untuk bias masuk dan melakukan pembaharuan.

5. Tipe kolot, yaitu masyarakat yang tidak mau menerima pembaharuan sebelum mereka benar-benar terdesak oleh lingkungan. ${ }^{7}$

Adapun proses da'wah yang dilakukan oleh Pondok Pesantren Darul Ulum dalam upaya pembaharuan dan pembinaan keagamaan Islam kepada masyarakat desa Sikakap menggunakan beberapa metode da'wah, sebagaimana tergambar dalam tabel dan narasi berikut :

${ }^{7}$ M. Bahri Ghazali, Da'wah Komunikatif, CV. Pedoman Ilmu Jaya: Jakarta, 1997, hal. 11-12 


\begin{tabular}{|c|c|c|}
\hline No & Meetode & $\begin{array}{l}\text { Aplikasi Pondok Pesantre } \\
\text { DarulUllum }\end{array}$ \\
\hline 1 & Pendekatan Personal & $\begin{array}{l}\text { - Da'wah bil-lisan (dengan } \\
\text { lisan) } \\
\text { - Pembagian daging qurban }\end{array}$ \\
\hline 2 & Pendekatan Pendidikan & $\begin{array}{ll}\text { - } & \text { Pendidikan dan pembinaan } \\
& \text { santri Al-Qur'an } \\
\text { - } & \text { Pembinaan guru Al-Qur'an } \\
\text { - } & \text { Pelatihan Imam dan } \\
& \text { Khatib } \\
\text { - } & \text { Pembinaan Muallaf }\end{array}$ \\
\hline 3 & Pendekatan Penawaran & $\begin{array}{l}\text { - Pengiriman santri } \\
\text { berprestasi ke pesantren di } \\
\text { luar Mentawai }\end{array}$ \\
\hline 4 & Pendekatan misi/bi'tsah & $\begin{array}{l}\text { - Pengiriman Imam dan } \\
\text { Penceramah Ramadhan }\end{array}$ \\
\hline
\end{tabular}

\section{Metode Da'wah billisan (dengan lisan)}

Metode da'wah bil lisan (dengan lisan) adalah metode da'wah yang dilakukan oleh seorang da'i dengan menggunakan lisannya pada saat melakukan aktivitas da'wah. Misalnya dengan cara ceramah, pidato, khutbah, dan lain-lain.

Dalam berda'wah membina keagamaan masyarakat, Pondok Pesantren Darul Ulum menggunakan metode da'wah bil lisan (dengan lisan) ini, yaitu dalam bentuk kegiatan pengajian rutin di majelis-majelis ta'lim yang ada di desa Sikakap.

Pengajian rutin di majelis-majelis ta'lim ini merupakan satu bentuk pembinaan keagamaan kepada masyarakat untuk menyeru masyarakat kepada hal yang ma'ruf dan mencegah perbuatan-perbuatan munkar yang dikhawatirkan akan muncul jika tidak diperhatikan dan dilakukan perubahan, serta sebagai upaya menghindarkan masyarakat dari kehinaan dan kemurkaan. Allah berfirman: 
'Dan hendaklahada di antarakamusegolonganumat yang menyerukepadakebajikan, menyurubkepada yang ma'ruf dan mencegahdari yang munkar, merekalab orang-orang yang beruntung”. (QS. Ali Imran : 104)

Dalam pelaksanaannya, pemateri pada pengaiian-pengajian rutin tersebut adalah para Pembina Pondok Pesantren Darul Ulum. Dan materi yang disampaikan pada setiap pengajian-pengajian tersebut dilakukan secara tematik sesuai dengan bidang atau latar belakang para Pembina Pondok Pesantren sebagai pemateri. Diantara materi-materi yang disampaikan pada setiap pengajian secara umum adalah materi-materi keIslaman dengan keadaan dan kebutuhan masyarakat.

Menjadi sunnatullah, bahwa dalam da'wah yang dilakukan akan menghadapi hambatan dan tantangan. Sebagaimana para Nabi dan Rasul terdahulu dalam menyampaikan da'wahnya, para Pembina Pondok Pesantren Darul Ulum yang terlibat dalam pembinaan masyarakat ini pun menemukan berbagai hambatan dan tantangan dalam da'wah mereka. Tantangan utama yang dihadapi adalah terjadinya perbedaan antar organisasi Islam dalam hal furu' (cabang) yang seharusnya bias ditoleransi, namun menimbulkan permasalahan. Sehingga pada sebagian kalangan menolak pemateri atau penceramah di luar kelompok mereka. ${ }^{8}$

\section{Pembagian Daging Qurban}

Bagi umat muslim, daging qurban merupakan daging yang halal untuk dikonsumsi. Syariat qurban merupakan salah satu ajaran yang Allah Swt. turunkan kepada Rasul-Nya. Namun

Syariat ini menjadi asing bagi sebagian kalangan kaum muslimin, terutama dari kalangan muallaf. Begitulah keadaan masyarakat pedalaman Sikakap. Sebagian ada yang tidak mengetahui adanya syariat berkurban. Bahkan mereka masih kental dengan budaya dan tradisi nenek moyang. Daging hewan-hewan yang diharamkan dalam agama Islam, seperti Babi,

\footnotetext{
${ }^{8}$ Iswandi, Mudir Pondok Pesantren Darul Ulum, Wawancara, Sikakap, Rabu 18 September 2019
} 
Anjing, Monyet dan sebagainya menjadi hal yang biasa mereka konsumsi turun temurun meskipun sudah meragama Islam.

Keadaan ini yang melatarbelakangi pengurus Pesantren Darul Ulum untuk mengumpulkan hewan qurban dari para pekurban di luar Sikakap dan dibagikan langsung kepada kaum muslimin di kampungkampung pedalaman Sikakap.

Para pequrban itu berasal dari lembaga-lembaga kemanusian, yayasan-yayasan Islam yang ada di luar Mentawai seperti Dewan Da'wah, Aksi Cepat Tanggap (ACT), Dompet Dhuafa, Rumah Zakat, Lazis Mitra Umat, Yayasan Peduli Mentawai dan instansi-instansi lainya.

Tidak kurang dari 15 ekor hewan qurban setiap tahunnya terkumpul di Pondok Pesantren Darul Ulum dari para pequrban di atas. Semua hewan qurban dipotong di lokasi Pesantren Darul Ulum, kemudian dagingnya baru diantar ke kampung-kampung kaum muslimin seluruh Sikakap.

Kegiatan ini bahkan bias menarik beberapa kaum muslimin yang ada di pelosok Sikakap, yang sudah lama melupakan Islam dan akan masuk agama Nasrani. Karena ketika dibagikan daging qurban, mereka merasa diperhatikan oleh saudara seiman mereka. Dan ternyata daging qurban sangat penting untuk menjaga akidah Islam di desa Sikakap. ${ }^{9}$

\section{Metode Pengajaran dan Pelatihan}

Metode da'wah ini dianggap penting untuk dilakukan dalam proses da'wah karena para da'i diharapkan memiliki keterampilan melakukan da'wah dikalangan masyarakat, memiliki kecakapan untuk menjelaskan berbagai focus kegiatan da'wah, serta mampu mengkaji dan memilih strategi da'wah yang sesuai dengan kondisi masyarakat yang dihadapi, sehingga da'wah yang disampaikan dapat tercapai sesuai dengan misi yang diharapkan.

\footnotetext{
${ }^{9}$ Iswandi, Mudir Pondok Pesantren Darul Ulum, Wawancara, Sikakap,
} Rabu 18 September 2019 
Dalam berda'wah membina keagamaan masyarakat, Pondok Pesantren Darul Ulum menggunakan metode pelatihan da'i yaitu dalam bentuk kegiatan, diantaranya:

a. Pendidikan dan Pembinaan santri Al-Qur'an

Pondok Pesantren Darul Ulum didirikan sebagai wadah pembinaan masyarakat terutama generasi muda berupa pendidikan dan Pembinaan Santri. Pendidikan yang ada di Pondok Pesantren Darul Ulum berbentuk Pembinaan di asrama dan pembinaan di sekolah formal. Sejak tahun 2017, Madrasah Aliyah (MA) yang didirikan Pesantren, masih konsisten melaksanakan kegiatan pendidikan dan pengajaran formal selama enam hari dalam sepekan.

Pondok Pesantren Darul Ulum berusaha mendidik santrinya agar mempunyai keunggulan dalam aspek spiritual, inteletual, dan professional. Kegiatan pendidikan yang ada merupakan perpaduan antara kurikulum agama dan kurikulum Pesantren. Melalui perpaduan kurikulum ini maka diharapkan terlahir alumni yang taat beribadah, melaksanakan shalat, puasa, dapat membaca, memahami, dan melaksanakan ajaran Al-Qur'an dan As-Sunnah, dapat membedakan yang baik dan yang buruk, cinta kemajuan, kritis, inovatif, analitis, dan bermanfaat bagi masyarakat. Hal ini merupakan bagian dari pengkaderan da’i. ${ }^{10}$

\section{b. Pembinaan Guru Al-Qur'an}

Dalam melakukan pembinaan keagamaan kepada masyarakat, Pondok Pesantren Darul Ulum melakukan suatu kegiatan yaitu Pembinaan guru Al-qur'an. Kegiatan ini dilaksanakan karena melihat keadaan di masyarakat khususnya di desa Sikakap yang masih banyak anak-anak belum mampu membaca $\mathrm{Al}$-Qur'an dengan benar, bahkan belum mampu membaca sama sekali. Kegiatan ini dilaksanakan dengan bentuk mengundang guru-guru TPA yang ada di pelosok desa Sikakap. Kemudian diberikan materi-materi yang berkaitan dengan metode pengajaran al-Qur'an pada anak didiknya dan juga materi tahsin Al-

${ }^{10}$ Iswandi, Mudir Pondok Pesantren Darul Ulum, Wawancara, Sikakap, Rabu 18 September 2019 
Qur'an untuk para guru-guru ngaji. Adapun pematerinya adalah sebagian Pembina Pesantren Darul Ulum yang ditunjuk.

Bukan hanya itu saja, Pesantren Darul Ulum juga memberikan perhatian khusus kepada seluruh guru-guru ngaji yang ada di pelosok Sikakap dengan mencarikan donator untuk tunjangan mereka serta untuk kebutuhan sarana dan prasarana TPA nya. Karena pada dasarnya belum ada tunjangan baik dari pemerintah setempat atau bahkan dari masjid masyarakat yang menganggarkan untuk memberikan tunjangan kepada guru-guru ngaji.

Kegiatan ini bukan hanya sebagai wadah silaturrahmi dengan guru-guru Al-Qur'an, tetapi juga sebagai sarana untuk menjalin hubungan yang erat dengan masyarakat pelosok desa Sikakap.

Kegiatan ini mendapatkan respon yang sangat baik dari tokohtokoh masyarakat dan tokoh agama setempat.

Dalam melaksanakan kegiatan da'wah ini, Pondok Pesantren Darul Ulum menghadapi berbagai hambatan diantaranya adalah kegiatan ini dilaksanakan hanya satu kali dalam sebulan karena permasalahan biaya serta jarak tempuh untuk menuju TPA-TPA yang ada di pelosok desa Sikakap. ${ }^{11}$

\section{c. Pelatihan Imam dan Khatib}

Keadaan desa Sikakap yang masih termasuk dalam 3T (terluar, terdalam, terasing) menjadi tantangan tersendiri untuk para juru da'wah setempat atau da'i dari luar daerah. Kondisi jalan yang masih sulit ditempuh mengakibatkan sedikitnya para khatib yang dapat memebrikan khotbah di masjid-masjid pelosok seluruh desa Sikakap. Karena itu sebagian masjid terkadang tidak melaksanakan kegiatan shalat jum'at.Demikian pula ketika di bulan Ramadhan, sebagian masjid terpaksa tidak dapat melaksakan shalat Tarawih dikarenakan tidak ada imam yang sanggup.

Melihat fenomina ini, maka Pondok Pesantren Darul Ulum mengambil andil dalam penyelesaian masalah ini. Para Pembina

${ }^{11}$ Lefrizal, PengajarPondokPesantrenDarulUlum, Wawancara, Sikakap, Sabtu 7 September 2019 
Pesantren Darul Ulum melihat penting untuk melakukan pengkaderan anak-anak setempat menjadi imam dan khatib.

Karena faktanya anak-anak Pesantren Darul Ulum berasal dari pelosok desa Sikakap, maka Pembina Pesatren Darul Ulum memberikan pembinaan khusus terhadap santri Pesantren Darul Ulum dalam masalah khutbah dan imam shalat. Diantara kegiatannya dengan memberikan materi khusus dan praktek khutbah bergiliran setiap selesai melaksanakan shalat Subuh.

Kegiatan ini sangat dirasakan manfaatnya ketika bulan Ramadhan, bersamaan dengan hari libur para santri, sebagian besar santri Pesantren Darul Ulum menjadi imam shalat Tarawih di kampungnya masingmasing, mulai dari santri yang masih duduk di bangku SMP sampai yang sudah di bangku SMA. Sebagian masjid yang ada di pusat Kecamatan Sikakap meminta imam tetap selama Ramadhan dari santri Pesantren Darul Ulum, bahkan masjid kapal Fery ASDP penyebrangan MentawaiPadang juga diisi oleh satri Pesantren Darul Ulum. ${ }^{12}$

\section{d. Pembinaan Muallaf}

Desa Sikakap merupakan desa dengan masyarakat yang majemuk, agama masyarakat pribumi adalah Nasrani, sedangkan agama Islam dianut oleh masyarakat pendatang. Seiring berjalannya waktu, masyarakat pribumi banyak yang tertarik untuk memeluk agama Islam. Di tahun 2019 ini, tidak kurang dari 35 orang yang terdaftar dalam data koordinasi muallaf desa Sikakap.

Pesantren Darul Ulum mempunyai andil dalam pembinaan muallaf tersebut. Iswandi sebagai mudir Pesantren Darul Ulum, hadir langsung dalam melakukan pembinaan dan perhatian khusus untuk para muallaf. Pembinaan dilakukan dengan mendukung baik moril maupun materil untuk pengajaran keIslaman dalam bentuk majelis ta'lim yang dilakukan dua kali dalam sepekan, bertempat di kantor badan koordinasi majlis ta'lim Sikakap, dan sesekali dilaksanakan di Pesantren Darul Ulum.

\footnotetext{
${ }^{12}$ AgusNadi, PembinaPondokPesantrenDarulUlum, Wawancara, Sikakap, Ahad 8 September 2019
} 
Perhatian khusus terhadap para Muallaf juga dilaksanakan dengan mencarikan donatur yang bersedia untuk membantu meningkatkan ekonomi para muallaf. ${ }^{13}$

Begitu juga Agus Nadi Sebagai Pembina Pesantren Darul Ulum, lebih focus terhadap pembinaan para muallaf yang ada di pelosok desa Sikakap. Walaupun hanya dilakukan sebulan sekali, karena terkendala jarak tempuh yang lumayan sulit. ${ }^{14}$

\section{Pengiriman Santri Berprestasi untuk Melanjutkan Sekolah}

Dalam rangka menumbuhkan semangat belajar dan menuntut ilmu para santri dan semangat para orang tua dalam mendukung anak nya dalam menuntut ilmu, maka Pondok Pesantren Darul Ulum memberikan penawaran-penawaran kepada seluruh santri dan orang tua bahwa siapa saja yang bias menampakkan keseriusan dalam menuntut ilmu, akan dicarikan beasiswa untuk melanjutkan sekolah di sekolah-sekolah luar Mentawai.

Program ini Sudah direalisasikan sejak tahun 2015, anak-anak Mentawai yang sudah dikirim untuk sekolah di pesantren favorit di luar Mentawai sampai tahun 2019 berjumlah enam orang mulai dari tingkat SMP sampai tingkat Kuliah ${ }^{15}$

Langkah ini sangat efektif untuk meningkatkan semangat belajar para santri, sehingga sebagian besar dari mereka berlomba untuk mendapatkan kesempatan ini.

\section{Pengiriman Imam dan Penceramah Bulan Ramadhan}

Pondok Pesantren Darul Ulum merupakan Pesantren yang menfokuskan kegiatannya dalam bidang menghafal Al-Qur'an. Para santri senior sudah memiliki hafalan lima juz atau lebih. Mereka juga dididik untuk menjadi imam dan khatib. Hal ini mendapatkan perhtian khusus dari masyarakat bahkan instansi-

\footnotetext{
${ }^{13}$ Farida Hanun, Ketua Koordinasi Majlis Ta'lim Sikakap, Wawancara, Sikakap, Sabtu 14 September 2019

${ }^{14}$ Agus Nadi, Pembina Pondok Pesantren Darul Ulum, Wawancara, Sikakap, Ahad 8 September 2019 15 ibid
} 
instansi pemerintah maupun swasta. Maka setiap bulan Ramadhan Pesantren Darul Ulum mengirim beberapa santrinya untuk menjadi imam tarawih sekaligus kultum Ramadhan. Seperti santri yang bernama Rino Chaniago pada Ramadhan tahun $1440 \mathrm{H}$ diutus untuk menjadi Imam dan penceramah di masjid kapal Fery milik ASDP penyebrangan Padang - Mentawai. Demikian pula santrisantri senior lainnya, diberikan jadwal imam dan penceramah di masjid-masjid sekitar desa Sikakap. ${ }^{16}$

\section{KESIMPULAN}

Berdasarkan penelitian yang dilakukan, penulis dapat menyimpulkan bahwa metode da'wah yang digunakan oleh Pondok Pesantren Darul Ulum dalam membina keagamaan masyarakat desa Sikakap adalah dengan empat pendekatan yaitu;

Pertama pendekatan personal dengan lisan, yaitu dengan diadakannya pengajian-pengajian atau ceramah rutin. Kedua pendekatan Pendidikan, yaitu dengan diadakanya pelatihan imam dan khatib, pelatihan Guru AlQur'an, dan Pembinaan Muallaf. Ketiga Pendekatan Penawaran yatiu dengan pengiriman santri berprestasi. Keempat pendekatan Misi/bi'tsah, yaitu dengan pengiriman imam dan penceramah bulan Ramadhan.

\section{DAFTAR PUSTAKA}

Al-Abrasyi, M. Athiyah, Dasar-dasar Pokok Pendidikan Islam,Jakarta : PT. Bulan Bintang, 1995, hal. 19

Amir, Samsul Munir, Ilmu Da'wah, Amzah : Jakarta, 2009, hal. xviii

Ghazali, M. Bahri, Da'wah Komunikatif, CV. Pedoman Ilmu Jaya : Jakarta, 1997, hal. 11-12

Iswandi, Mudir Pondok Pesantren Darul Ulum, Wawancara, Sikakap, Rabu 18 September 2019

\footnotetext{
${ }^{16}$ ibid
} 
Mujib, Abdul, Ilmu Pendidikan Islam,Jakarta: Kencana Penada Media, 2006, hal. 234-235

Zazin, Nur, Gerakan Menata Pendidikan (Teori dan Aplikasi),Jogjakarta : Arruzz Media. 2011, hal.21

\section{Wawancara}

Iswandi, Mudir Pondok Pesantren Darul Ulum, Wawancara, Sikakap, Rabu 18 September 2019

Lefrizal, Pengajar Pondok Pesantren Darul Ulum, Wawancara, Sikakap, Sabtu 7 September 2019

Agus Nadi, Pembina Pondok Pesantren Darul Ulum, Wawancara, Sikakap, Ahad 8 September 2019

Farida Hanun, Ketua Koordinasi Majlis Ta'lim Sikakap, Wawancara, Sikakap, Sabtu 14 September 2019

\section{Dokumen}

Arsip Desa Sikakap, Profil Desa Sikakap, Kecamatan Sikakap, Kabupaten Kepulauan Mentawai, Provinsi Sumatera Barat 2019

\section{PEDOMAN TRANSLITERASI}

Transliterasi Arab-Latin digunakan dalam jurnal Ilmu Dakwah Academic Journal for Homiletic Studies berdasarkan model Library of Congress, sebagai berikut:

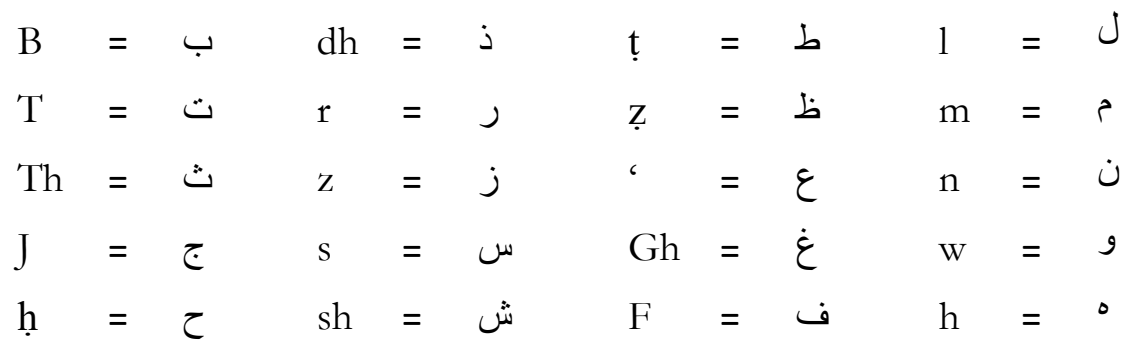




$\begin{array}{llll}\mathrm{Kh}=\dot{\mathrm{C}} & \mathrm{S}=\boldsymbol{Q} & = \\ \mathrm{D}=\mathrm{Q} & \mathrm{d}=\boldsymbol{\mathrm { d }} & =\end{array}$

Pendek $\quad \mathrm{a}=\ldots ; \mathrm{I}=-\quad \mathrm{u}=\dot{\mathrm{L}}$

Panjang $\overline{\mathrm{a}}=\mathrm{L} ; \overline{\mathrm{I}}=\mathrm{v}, \quad \overline{\mathrm{u}}=\mathrm{g}$

Difthong ay $=$ أيّ $\quad$ a $=$

1. Kata berakhiran ta marbüthah (¿) ditransliterasi tanpa menggunakan "h"; jika huruf berada di depan ta marbüthah ditransliterasi menjadi " $\mathrm{t}$ ".

2. Huruf alif-läm (ال) ditransliterasi menjadi al-; jika berada setelah preposisi maka hurufalif-làm ditransliterasi menjadi $l$.

3. Ayat Qur'anditransliterasi sesuai dengan pengucapan. Contoh:

a. Bahasa Arab umum:

$$
\begin{aligned}
& \text { = Abliyyah atauabliyya } \\
& \text { = Sürat al-Baqarah } \\
& \text { = Abl as-sunnah wa 'l-jamäah }
\end{aligned}
$$

b. Ayat Qur'an: 